\title{
The Effect of Health Education through Video on Girls with Visual and Hearing Disabilities' Knowledge about Sexually Transmitted Infections
}

\author{
Ulfa Latifah ${ }^{1}$, Dini Saraswati Handayani ${ }^{1}$, Fardila Elba ${ }^{1}$, Ari Indra Susanti ${ }^{1}$, Neneng Martini ${ }^{1}$ \\ ${ }^{1}$ Universitas Padjadjaran, Indonesia
}

\begin{abstract}
Girls with disabilities are more at risk of contracting STIs because they are a vulnerable group, lacking information and reproductive health services so that hygiene is not well maintained. This study aimed to determine the effect of health education through a video about STIs on the knowledge of girls who were blind and deaf in Bandung City. This study used a pre-experimental method with one group pretest-posttest design in October-December 2019. The research sample was girls who were blind and deaf at Extraordinary Schools in Bandung City. The sampling technique was total sampling with 63 respondents. Data collection was carried out by interviews and questionnaire. Bivariate data analysis used Paired T-Test. In this study, there was an effect of health education through video on the knowledge of girls who were blind and deaf about STIs.
\end{abstract}

Keywords: Video, Knowledge of girls, Visual and hearing disabilities; Sexually Transmitted Infections

\section{Research Background}

Adolescence is closely related to changes the physical, psychological, and thought patterns. These changes are able to trigger the attitudes and behavior of adolescents to have high curiosity, like the challenges, and be attracted to the opposite sex. The date activities of girls were $64 \%$ were holding hands, $17 \%$ were hugging, $30 \%$ were kissing lips, and $5 \%$ were touching or getting touched the sensitive parts of the body (National Family Planning Coordinating Board et.al, 2018).

Those risky date activities are able to lead to promiscuous sexual behavior that permits for Sexually Transmitted Infections (STIS). The girls at age 15-19 in the United States were getting chlamydia as much as 3265.7 cases per 100,000 girls population, 557.4 cases of gonorrhea, and 3.2 cases of syphilis (Centers for Disease Control, 2018). In Indonesia, there were $43.5 \%$ of chlamydia cases, $28.6 \%$ of gonorrhea,

$8.7 \%$ of syphilis, and $19.2 \%$ of others (Tanudyaya F et.al, 2010 ). If some types of STIs are not treated promptly, they will increase the risk of HIV/AIDS transmission. In 
Indonesia, there were around 630,000 people with HIV/AIDS (World Health Organization, 2017).

Half of STIs new cases are occurred by people at age 15-24 (Centers for Disease Control, 2018). According to the United Nations Fund for Population Activities (UNFPA) and WHO, 1 in 20 adolescents contracted STI every year. Girls are more risky to obtain STIS because the female reproductive organs are more vulnerable and lack of maintenance (National Family Planning Coordinating Board, 2012).

The incidence of STIs transmission are able to occur in adolescents with disabilities and non-disabilities. According to the Law of the Republic of Indonesia No. $8 / 2016$ on Persons with Disabilities, a person with disability is someone who has physical, intellectual, sensory, and/or mental disabilities for a long period of time, interacts with the surrounding environment is able to have obstacles to participate fully with others based on equal rights.

The number of persons with visual and hearing disabilities in Bandung City is the biggest population after physical and mental disabilities. In Bandung, there were 243 persons with visual impairment and 309 persons with hearing loss. This city also has the largest disabilities population in West Java which are about 8,038 people (Bandung City Population and Civil Registration Department, 2017).

According to the International Planned Parenthood Federation (2013), persons with disabilities are a vulnerable group and have the lack of health information, education, and reproductive health services. Three factors which are able to influence a person's health behavior are the predisposing factor, enabling factor, and reinforcing factor. Knowledge is one of the crucial bases that must be possessed so that girls with disabilities have healthy behaviors (Wijayanti et.al, 2017). Research conducted by Nari et.al, (2015) elucidated that $44 \%$ of adolescents had less knowledge about STIs. Besides that, Gaferi et.al, (2018) in their research depicted that on average $60.12 \%$ of girls did not know about STIs.

One of the efforts to increase the knowledge of girls with visual and hearing disabilities about STIs is to conduct health education using audiovisual media in the form of a video because it is more interesting and suitable for them to maximize their senses in the understanding process. Based on the research of Meidiana et.al, (2018), there was a significant increase on the knowledge of overweight adolescents after being given health education by video. Furthermore, other research revealed that video is effective to escalate the knowledge about HIV/AIDS among adolescent students in Parigi, Pangandaran District (Handayani, 2017).

As far as researchers' knowledge, there is no data about the knowledge of STIs focusing on girls with visual and hearing disabilities in Indonesia, particularly in Bandung City. Thus, this study aimed to determine the effect of health education through video on 
the knowledge of girls with visual and hearing disabilities about Sexually Transmitted Infections (STIs) in Bandung City.

\section{Research Methodology}

This study utilized the pre-experimental method with one group pretest-posttest design. This study was only conducted in one group without a comparison group. In this study, girls with visual and hearing disabilities were given a pretest $\left(\mathrm{O}_{1}\right)$ to find out their knowledge about STIs. The intervention $(\mathrm{X})$ was given by the researchers which was health education through a video. After that, they were given a posttest $\left(\mathrm{O}_{2}\right)$ to determine the increase of knowledge about STIs.

The sampling technique was total sampling which was 63 girls with visual and hearing disabilities at ages 15-21 at Extraordinary Schools in Bandung City.

In this study, the inclusion criteria were female students at ages 15-21 at Extraordinary Schools in Bandung City who had visual or hearing disabilities. Thus, the exclusion criteria were students with multiple disabilities.

The data collection was conducted in October-December 2019, taken from the primary data by interviews and using a questionnaire as research instruments which had tested the validity and reliability with a total of 30 questions used a Guttman Scale with true or false answer options. The measures of data collection in this study were:

1. Researchers explained to the schools about the procedures, research purposes, and girls with blind and deaf as the respondents.

2. Researchers distributed the informed consent sheet to the parents or teachers.

3. Researchers explained the procedures for filing and answering the questionnaire.

4. Researchers organized a pretest for 20-30 minutes for each respondent to find out the respondent's knowledge of STIs.

a. Girls with visual impairment: the questionnaire questions were read out by the researchers.

b. Girls with hearing loss: interviews were conducted using sign language by teachers' help and shown pictures which were relevant to the questions.

5. Respondents were given health education through a video about STIs for \pm 8 minutes.

6. Researchers hold a posttest with a questionnaire and the same technique as the pretest to determine the knowledge of girls with visual and hearing disabilities about STIs after being given intervention.

After collecting the data, the researchers carried out the data processing and analysis stages. Data from the pretest and posttest results were inputted and processed using Microsoft Excel and SPSS. Bivariate data analysis used Paired T-Test. 
The cumulative knowledge of students was measured and categorized based on Bloom's cut-off points: ('Adilah, 2015)

1. Good knowledge: a score of $80 \%-100 \%$.

2. Moderate knowledge: a score of $60 \%-79 \%$.

3. Poor knowledge: a score $\leq 59 \%$.

\section{Results and Discussion}

This chapter reveals an overview of the results from the univariate and bivariate analyses which attempted to assess how much they knew about the information of STIs such as the definition, the causes, the ways of transmission, the symptoms, the types of STIs, and the ways of prevention.

Table 1. Respondents Characteristics ( $N=63$ )

\begin{tabular}{|l|c|c|}
\hline \multicolumn{1}{|c|}{ Characteristics } & Frequency & Percentage (\%) \\
\hline Age & & \\
$15-17$ & 41 & 65.1 \\
$18-21$ & 22 & 34.9 \\
\hline Education & & \\
Primary School & 8 & 12.7 \\
Junior High School & 21 & 33.3 \\
Senior High School & 34 & 54.0 \\
\hline Type of Disability & & \\
Visual impairment & 15 & 23.8 \\
Hearing impairment & 48 & 76.2 \\
\hline Main Source of STI Information & & \\
Parents & 9 & 14.3 \\
School teachers & 6 & 9.5 \\
Friends & 4 & 6.3 \\
Health workers & 3 & 4,8 \\
Mass media & 5 & 7.9 \\
None & 36 & 57.1 \\
\hline
\end{tabular}

Most of the respondents were 15-17 years old (65.1\%). Looked at the level of education, they were Senior High School students (54.0\%) and had a hearing loss (76.2\%). Furthermore, they claimed that they had not received any information about STIs (57.1\%). 
Table 2. Knowledge of Respondents regarding STIs Before and After Being Given Intervention (N $=63)$

\begin{tabular}{|l|c|c|c|c|}
\hline \multirow{2}{*}{ Knowledge } & \multicolumn{2}{c|}{ Pre-test } & \multicolumn{2}{c|}{ Post-test } \\
\cline { 2 - 5 } & Freq & $\%$ & Freq & $\%$ \\
\hline Good & 0 & 0 & 15 & 23.8 \\
Moderate & 25 & 39.7 & 32 & 50.8 \\
Poor & 38 & 60.3 & 16 & 25.4 \\
\hline
\end{tabular}

The respondents' knowledge of STIs during the pre-test found that the highest number was the poor category (60.3\%). After being given health education through video, their knowledge obtained the highest score in the moderate category (50.8\%). So, it is able to be concluded that there is an increase on knowledge before and after being given health education using video.

Table 3. Effect of Health Education through Video on The Knowledge of Respondents regarding STIS

\begin{tabular}{|l|c|c|c|c|c|}
\hline \multicolumn{1}{|c|}{ Know-ledge } & Mean & SD & Median & p-value & r \\
\hline Pre-test & 53.92 & 12,736 & 53.33 & 0,000 & 0.573 \\
Post-test & 67.51 & 12,298 & 70.00 & & \\
\hline
\end{tabular}

The average knowledge of girls with visual and hearing disabilities before being given the intervention was 53.92. One week after being given health education using video, the average value was 67.51 . The results of Paired Samples T-Test analysis depicted that there was an effect of giving health education through video on enhancing the knowledge of girls with visual and hearing disabilities regarding STIs between pre-test and post-test $p$-value $=0.000(p<0.05)$ and has strong influence $(r=0.573)$.

Blindness and vision impairment is someone with a deficiency or loses the ability to see in normal light conditions or even helped by using glasses (Mardiyati, 2016). Deafness and hearing loss is someone unable to hear normally, the hearing thresholds in both ears is $\geq 25 \mathrm{~dB}$, is said to have hearing loss (World Health Organization, 2018).

The results of the analysis depicted that most of girls with visual and hearing disabilities had not received any information about STIs. Information is a source of knowledge. If someone gets a lot of information, their knowledge will increase (Maulina, 2015). This study implied that the surroundings such as parents, schools, and health workers had not fully paid attention to children with special needed regarding sexual education, particularly about STIs. Their needs are often neglected because of the perception that women with disabilities are not sexually active and do not need information about sexual health. They have a considerable risk of being sexually harassed and even raped (Bremer et.al, 2009). 
Researchers had not found the previous research about STIs with girls who were blind and deaf as the respondents. However, there was a quite similar study where the result of this study was different with the research conducted by Dartiwen (2017) which stated that most of the students at Lohbener Senior High School in Indramayu had sufficient knowledge about STIs.

Six levels of knowledge according to Bloom's Taxonomy are to remember, understand, apply, analyze, evaluate, and create (Rukmini, 2008). In this study, girls with visual and hearing disabilities passed the remembering stage by recalled the STIs information which had known in advance, and the level of their knowledge was measured by a pretest. Then, the next level was the understanding stage to explain and interpret STIs accurately which was quantified by the posttest.

In this study, the normality test was carried out by the Kolmogorov-Smirnov because the sample total was upper than 50 respondents, obtained $p$-value $>0.05$ which meant that the data were distributed normally. Researchers had not found the studies concerned at a similar topic or respondent. However, this is quite in line with the study conducted by Meidiana et.al, (2018) who found that there was a significant increase on the knowledge of overweight adolescents $(p=0.000)$ after being given video as a media of health education. Furthermore, the video was an effective way to escalate the knowledge among adolescent students in Parigi, Pangandaran Regency with p-value $=0,000$ (Handayani, 2017).

Health education aims to empower people through their knowledge so that they are able to have a healthy life as expected (Yusriani \& Alwi, 2018). It is in line with the behavioral theory from Lawrence Green that the knowledge of a person is able to influence his/her behavior in taking action. It means that knowledge of girls with disabilities about STIs is one of the fundamentals that must be possessed so that they have healthy behaviors and avoid STIs transmission.

Girls with visual impairment are able to gain information verbally, such as listening and speaking activities. Then, those will create reflections which are combined into a unit so that it can make new information in their thoughts (Muthmainnah, 2015). Moreover, adolescents with hearing loss can obtain the information by maximizing the function of their vision to read (Agusta R et.al, 2015). However, their abilities to understand something through video will be a bit late because the process of understanding using pictures and words takes a longer time. After all, it must be expressed concretely through demonstrations or gestures and using language which is easy for them to understand (Mangunsong, 2011). Thus, the researchers inserted the sign language translation video to make it easier for them to catch the meaning.

Video as a media in health education is a tool to convey information about health because it is considered as an easier way to send messages to the targets. Its advantages are widely known by the people, involves many senses, easier to understand, more 
interesting because there are sounds and animations, and the presentation is able to be controlled as needed (Yusriani \& Alwi, 2018). The video content in this study was an amalgamation of animated images, words, audios, and sign language interpreters which were understood easily by girls with disabilities so that it would not be difficult for them to receive information about STIS.

\section{Conclusion}

The characteristics of girls with visual and hearing disabilities were mostly at ages 15-17, as Senior High School students, had hearing loss, and claimed that they had not received information about STIs. Their knowledge before being given health education were in the poor category, and after that, it increased to the moderate category. It showed that there was an increase on their knowledge before and after being given intervention. The results showed that there was effect of health education through video on the knowledge of girls with visual and hearing disabilities regarding STIs between pre-test and post-test and had a strong influence.

\section{Bibliography}

'Adilah. (2015). Gambaran Kebutuhan Pelayanan Kesehatan Reproduksi bagi Remaja Penyandang Cacat di SMPLB dan SMALB TPA Bintoro Kabupaten Jember (Thesis that not published, Universitas Jember), 46. Accessed from http://repository.unej.ac.id/bitstream/handle/123456789/73710/Adiilah.pdf?sequ ence $=1 \&$ isAllowed $=y$.

Agusta, M. V. (2015). Hubungan Pengetahuan Kesehatan Gigi dengan Kondisi Oral Hygiene Anak Tunarungu Usia Sekolah. Semarang: Medali Jurnal Media Dental Intelektual, 2, 65.

BKKBN. (2012). Buku Suplemen Bimbingan Teknis Kesehatan Reproduksi Infeksi Menular Seksual dan HIV/AIDS. Jakarta: Badan Kependudukan dan Keluarga Berencana Nasional (BKKBN).

BKKBN, BPS, Kemenkes. (2018). Survei Demografi dan Kesehatan Indonesia 2017 Buku Remaja. Jakarta: BKKBN, BPS, Kemenkes.

Bremer, K., Lynn, C., Acheinegeh, R. (2009). Reproductive Health Experiences Among Women With Physical Disabilities In The Northwest Region Of Cameroon. Cameroon: International Journal of Gynecology and Obstetrics, 10 (8), 211-213.

Centers for Disease Control. (2017). Gonorrhea - CDC Fact Sheet. Georgia: Centers for Disease Control.

Centers for Disease Control. (2018). Sexually Transmitted Disease Surveillance 2017. Georgia: Centres for Disease Control and Prevention.

Communicable Disease Control Directorate. (2013). Chlamydia. Western Australia: Department of Health.

Communicable Disease Control Directorate. (2013). HIV/AIDS. Western Australia: Department of Health. 
Dartiwen. (2017). Pengetahuan Siswa tentang Infeksi Menular Seksual (IMS) di SMA Negeri 1 Lohbener Kabupaten Indramayu Tahun 2017. Indramayu: SURYA, 09 (02), 3.

Davis, B., Summers, M. (2015). Applying Dale's Cone of Experience to increase learning and retention: A study of student learning in a foundational leadership course. Qatar: QScience Proceedings, 6.

Deafness and hearing loss - World Health Organization. (2018). Retrieved January 04, 2019, from https://www.who.int/news-room/fact-sheets/detail/deafness-and-hearingloss.

Dinas Kependudukan dan Pencatatan Sipil. (2017). Jumlah Penduduk Penyandang Disabilitas Di Kota Bandung Per Kelurahan Tahun 2016. Bandung: Open Data Kota Bandung.

Gaferi, S. M., Al-Harbi, M. F., Yakout, S. M., Soliman, A. T. (2018). Knowledge, attitude and practice related to reproductive health among female adolescents. Riyadh: Journal of Nursing Education and Practice, 8 (8), 58.

Handayani, L. (2017). Pengaruh Pendidikan Kesehatan dengan Media Video terhadap Tingkat Pengetahuan tentang Pencegahan HIV/AIDS di SMA Negeri 1 Parigi Kabupaten Pangandaran (Thesis that not published, Universitas 'Aisyiyah Yogyakarta). Accessed

from http://digilib.unisayogya.ac.id/2753/1/NASKAH\%20PUBLIKASI.pdf.

International Union Against Sexually Transmitted Infections. (2010). Syphilis. Europe: International Union Against Sexually Transmitted Infections.

Jannah, N., Rahayu, S. (2017). Kesehatan Reproduksi \& Keluarga Berencana. Jakarta: EGC.

Kasa, T. A., Luck, T., Bekele, A., Riedel-Heller, S. G. (2016). Sexual and reproductive health of young people with disability in Ethiopia: a study on knowledge, attitude and practice: a cross-sectional study. Leipzig: Kassa et al Globalization and Health, 12 (5), 3.

Kementerian Kesehatan RI. (2015). InfoDATIN: Situasi Kesehatan Reproduksi Remaja. Jakarta. Kementerian Kesehatan RI, 1.

Maftuhin, A. (2017). Mendefinisikan Kota Inklusif: Asal-Usul, Teori dan Indikator. Semarang: Tata Loka, 19 (2), 102.

Mahler, K. J. (2009). Hygiene and Related Behaviors for Children and Adolescents with Autism Spectrum and Related Disorders. USA: Autism Asperger Publishing Co.

Mangunsong, F. (2011). Psikologi dan Pendidikan Anak Berkebutuhan Khusus. Jakarta: LPSP3 UI.

Mardiyati, U. (2016). Modul Guru Pembelajar PLB Tunanetra Kelompok Kompetensi D. Bandung: Pusat Pengembangan dan Pemberdayaan Pendidik dan Tenaga Kependidikan Taman Kanak-Kanak dan Pendidikan Luar Biasa, Kementerian Pendidikan dan Kebudayaan RI.

Maulina, R. (2015). Faktor-faktor yang Berhubungan dengan Pengetahuan tentang PAP Smear pada Wanita Usia Subur (WUS) di Pemukiman Lamnga Kecamatan Mesjid Raya Kabupaten Aceh Besar. Aceh: Jurnal Kesehatan Masyarakat, 7. 
Meidiana, R., Simbolon, D., Wahyudi, A. (2018). Pengaruh Edukasi melalui Media Audio Visual terhadap Pengetahuan dan Sikap Remaja Overweight. Bengkulu: Jurnal Kesehatan, 9 (3), 480-483.

Muthmainnah, R. N. (2015). Pemahaman Siswa Tunanetra (Buta Total Sejak Lahir dan Sejak Waktu Tertentu) Terhadap Bangun Datar Segitiga. Jakarta: FIBONACCI (Jurnal Pendidikan Matematika dan Matematika), 1 (1), 16.

Nari, J., Shaluhiyah, Z., Nugraha, P. (2015). Analisis Faktor-Faktor yang Berhubungan dengan Kejadian IMS pada Remaja di Klinik IMS Puskesmas Rijali dan Passo Kota Ambon. Ambon: Jurnal Promosi Kesehatan Indonesia, 10 (2), 139.

Potter, A., Perry, A. G., Stockert, P. A., Hall, A. M. (2017). Fundamentals of nursing. ninth ed. St. Louis: Mosby Elsevier.

Primadata, A., Soemanto, R., Haryono, B. (2015). Tindakan Orangtua Dalam Menyekolahkan Anak Berkebutuhan Khusus Pada Layanan Pendidikan Inklusif di Sekolah Dasar Negeri 1 Tanjung, Kecamatan Purwokerto Selatan, Kota Purwokerto. Purwokerto: Jurnal Analisa Sosiologi, 4 (1), 8.

Putro, K. Z. (2017). Memahami Ciri dan Tugas Masa Perkembangan Remaja. Yogyakarta. APLIKASIA: Jurnal Aplikasi Ilmu-ilmu Agama, 17 (1), 25.

Rahmasari, P., Nurhaeni, I. D. A., Sulaeman, E. S. (2016). Precede and Proceed Model on the Determinants of Teacher's Role in the Provision of Reproductive Health Education for Students with Mild Mental Retardation at School of Disability in Sleman, Yogyakarta: Journal of Health Promotion and Behavior, 1 (2), 111.

Rukmini, E. (2008). Deskripsi Singkat Revisi Taksonomi Bloom. Yogyakarta: Majalah Ilmiah Pembelajaran, 4 (2).

Sen, E., Yurtsever, S. (2017). Difficulties Experienced by Families with Disabled Children. Journal for Specialists in Pediatric Nursing, 12 (4).

Sidik, J. (2018). Analisis Faktor-Faktor yang Mempengaruhi Tingkat Kesadaran Pendidikan Jenjang SMA dan Sederajat di Dusun Nagrak Desa Sedong Kidul Kecamatan Sedong Cirebon (Thesis that not published, UIN Syarif Hidayatullah), 18. Accessed from http://repository.uinjkt.ac.id/dspace/bitstream/123456789/42138/1/JAFARFITK.pdf.

Tanudyaya, F., et al. (2010). Prevalence of sexually transmitted infections and sexual risk behavior among female sex workers in nine provinces in Indonesia, 2005. Southeast Asian J Trop Med Public Health, 41 (2), 463-473.

Undang-Undang Republik Indonesia Nomor 8 Tahun 2016 Tentang Penyandang Disabilitas.

Undang-Undang Republik Indonesia Nomor 20 Tahun 2003 tentang Sistem Pendidikan Nasional.

Wawan, A., Dewi, M. (2010). Teori \& Pengukuran Pengetahuan, Sikap, dan Perilaku Manusia. 1 ed. Yogyakarta: Nuha Medika, 16-17.

Wijayanti, E., Dewi, C., Rifqatussa'adah. (2017). Faktor-faktor yang Berhubungan dengan Perilaku Merokok pada Remaja Kampung Bojong Rawalele, Jatimakmur, Bekasi: Global Medical and Health Communication, 5 (3), 195. 
94 | Indonesian Journal of Disability Studies

World Health Organization. (2016). Report on global sexually transmitted infection surveillance 2015. Geneva: World Health Organization.

World Health Organization. (2017). Kajian Nasional Respon HIV di Bidang Kesehatan Republik Indonesia. Jakarta: World Health Organization.

Yusriani, Alwi, M. K. (2018). Promosi Kesehatan dan Pemberdayaan Masyarakat. Ponorogo: Forum Ilmiah Kesehatan, 1. 